\title{
チセとトイチセの冬期の熱環境性能に関する研究 THERMAL ENVIRONMENT OF CHISE AND TOICHISE IN WINTER SEASON
}

\author{
森 太郎*, 西澤岳夫**, 桑原浩平 ${ }^{* *}$, 佐 藤彰治*** \\ Taro MORI, Takeo Nishizawa, Kouhei KUWABARA \\ and Syoji SATOU
}

\begin{abstract}
Recently, people pay attention to a life style of Ainu people who live in Hokkaido and north Asia area as indigenous people. Chise is a traditional house for them. They are made of just local materials such as wood and cogon grasses. In this report, we made two different types of Chise and measure the thermal environments and the skin temperature of the research participants in severe cold weather. The results indicate thermal environment in each Chise is very poor (Toichise is better than Chise). They probably had some method except housing to get warm in cold environment.
\end{abstract}

Keywords : Thermal performance, Measurement, Ainu people, Traditional housing 熱性能，実測，アイヌ，伝統住宅

\section{1. 研究の背景と目的}

近年, 地球環境問題の顕在化によって持続可能な社会の実現が求 められている. そのような状況のなかにあって, 北海道, 東北の先 住民族であるアイヌのライフスタイルに注目が集まっている.アイ 又は日本や北東アジア，ロシアに居住する北方先住民族である。も ともと日本列島全土に居住していた縄文人をベースとして北アジア 等の影響を強く受けた民族であり, 近年まで特有の価值観を持ち, 北方地域の自然と共生してきたとされている。住生活に関しても,

「チセ」とよばれる独特の住居で暮らしていたが，アイヌは文字を 持たなかったため，その様式や住生活に関する資料はそれほど多く なく1), 想像で記述されているものも多い. しかし, 極寒の地域で長 く,それも地域に根差した生活をしてきたという事実は, 例えば, 暖房設定温度の見直し, 適切な室内着, 木質バイオマスを活かした 暖房等, これからの私たちの持続可能なライフスタイルにとって重 要な参考事例になるに違いない.

本報告では, 二棟の復元チセ（チセとトイチセ）を利用し, 冬期 にその内部に形成される室内環境と投入エネルギーの関係を明らか にし，冬期のアイヌの住生活と住居に関する考察を行うことを目的 とする.

\section{2. チセ, トイチセに関する既往の研究}

チセは, アイヌの住居の総称である. 周辺から得られる自然木を
素材とした簡素な木造建築で, 掘立柱を地面に直に立て, 柱と梁を 組んで屋根を支えた寄棟の掘立柱建物とされている2). 主な建築材 は木材と茅であるが，屋根や壁を莫く材料として，樹皮や笹が利用 されていたという事例もある。前述のようにアイ又は文字を持た ず，口承で作り方が伝えられてきたため資料は多くないが，江戸時 代末期から明治期にかけての絵画, 写真, また 1900 年代に入っての 文化人類学的な調查は数多く行われ，千セがじのような住居であっ たかに関しては数多くの研究がなされている. 古くは鷹部屋福平に よる調査が実施され「アイヌの生活文化」，「アイヌの住居」が知 られている. 近年のものでは小林考二3)によるチセの形式に関する 研究が良く知られている. また, トイチセのトイとは土を意味し, 穴居形式の住居を表している. 北海道にもあったのではないかと言 われているもののトイチセに関する資料は非常に少なく, 樺太アイ ヌやニブヒ族に関するに関する資料10119)がいくつかあるのみであ る. 文献19には色丹の土の家に関する写真, 図が掲載されており, 土の家は，主に冬の間のベッドルームとして使用されていたようで ある。

また，それぞれのチセの居住環境に関する文献は非常に少ない. もちろん，チセの中のアイヌの生活に関する幾つかのコメントから その生活の一端は想像できるのであるが，それらのコメントと上記 の建築様式がもたらすであろう温熱環境にはギャップがある. チセ に実際に居住し実測調查を行った研究例として, 窪田ら4は, チセ
* 北海道大学大学院工学研究院 准教授・博士 (工学 $)$

***釧路工業高等専門学校建築学科 准教授·博士 (工学)

*** 釧路工業高等専門学校建築学科 教授 · 博士 (工学)
Assoc. Prof., Faculty of Eng., Hokkaido Univ., Dr.Eng.

Assoc. Prof., Dept. of Arch., Kushiro National College of Technology, Dr.Eng.

Prof., Dept. of Arch., Kushiro National College of Technology, Dr.Eng. 
における気温・グローブ温度・ガス濃度 $\left(\mathrm{CO}_{2}, \mathrm{CO}\right)$ などの 14 ケに わたる実測調查を実施している。調査対象となったチセは, 床面積 が約 $20 \mathrm{~m}^{2}$, 高さが梁まで約 $1.8 \mathrm{~m}$, 棟木までが約 $3.6 \mathrm{~m}$ ある茅莫き のもので, 少人数の家族に用いられる大きさの住居である. 換気孔 (煙空) は $2 つ$ 合わせて $0.15 \mathrm{~m}^{2}$ 程度, 空は東壁に 1 ヶ所, 南壁に 2 ヶ所 設けられており, それぞれ $0.4 \mathrm{~m}^{2}(70 \times 60 \mathrm{~cm})$ 程度である. 茅莫の厚 さは屋根が $27 \sim 42 \mathrm{~cm}$, 壁が $10 \mathrm{~cm}$ の厚みを有しており，どちらも直 径約 $10 \mathrm{~cm}$ の茅束で莫いたものである。床は土間に茅を2 3 層置い て，その上に茅でできた寸だれを敷いて仕上げられている。この研 究で窪田らは冬期の非常に厳しい環境とチセの換気特性 (囲炉裏の 必要換気量) について, 囲炉裏で火を焚くことで発生する上昇気流 の巻込み風量に対応するだけの外気が居住区に供給されなければ, 一度上昇した煙が降下して再び上昇気流に巻き込まれるという循環 流を形成することになることを報告している．

同じく, 1989年に宇佐美らも前述と同様な調査が行われていた $5,6,7)$. 調查対象のチセは 2 棟あり, 1 棟が床面積 $39 \mathrm{~m}^{2}$ の中位のも の, もう1棟が床面積 $45 \mathrm{~m}^{2}$ の大きめのものであった。 ただし, 屋 根・壁はどちらも笹で莫かれている。この研究では特に土間床への 蓄熱が注目され, 地表面と地下 $10 \mathrm{~cm} の$ 温度が常に $2^{\circ} \mathrm{C}$ 前後で安定し ている地下 $30 \mathrm{~cm} の$ 地中温度と同じになっていたことが報告され， このような地盤への蓄熱は北方先住民族であるアイヌの生活の知恵 であろうとしている.

以上の研究結果は, 当時も議論があったようだが床面の蓄熱に関 して異なった見解を有している。つまり, 窪田らの研究においては 床面はほぼ断熱されているため地盤の蓄熱は無視され, 宇佐美らの 研究においては, 継続して薪を燃焼させることで有効な放熱量を地 面から得ることができると考えているからである，本報告では，こ れらの測定時には実施されていなかった，チセ，断熱改修于セ，ト イチセの比較の実施，サーモカメラによる表面温度分布の測定，標 準発熱を用いたチセ，トイチセの室内環境比較を行うことで，より 詳細にチセの建物特性を把握し, 彼らの生活様式の解明の一助とす るものである.

\section{3. チセ, トイチセの建設}

\section{1 復元チセの建設}

本研究は科学研究費補助金, 基盤研究 $\mathrm{C} 「$ 北方先住民族住居を用 いた実践的教育プログラムの開発」の一部として実施されている 8,9). したがって，復元チセの建設は，所謂，「ものづくり教育」 の一環として実施されたものである。建設に先立ち，チセに関する 文献・史資料の調查と復元チセの見学を行い, 基本的な事柄を調査 した上で, 縮尺 $1 / 5$ の木製模型を学生主体で作成, 構造的特徵や構 法に対する理解を深め, その後, 釧路工業高等専門学校敷地内に建 設位置を確定，建設に取りかかった。工事は2011年4月26日から開 始し，同年12月22日にほぼ終了した（Fig.1）。建物の建設作業は 建設機械など一切使わず，参加者の手仕事のみで行い， 1 人工 5 時 間相当の作業として, 概算で延べ 164 人工を要した。 チセの構造は Fig.2の左側に示すように木造平家建てで寄棟造りである。規模は 梁間と桁行はそれぞれおよそ $2445 \mathrm{~mm}$ と $3510 \mathrm{~mm}$ で，柱が外踏し張 りの構造になっているため, 柱根元では 6 畳程度の矩形平面となっ ている.
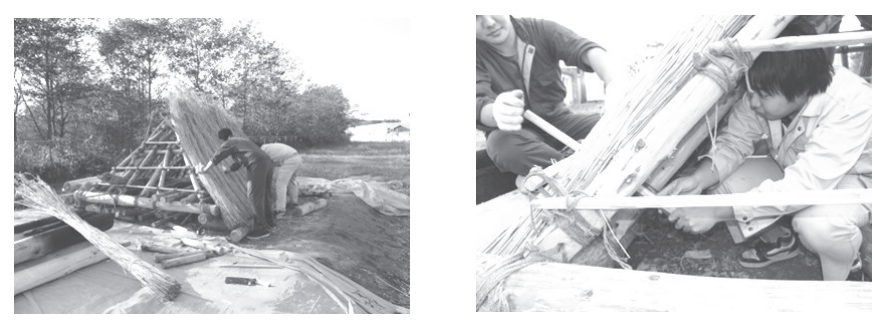

Construction of the roof
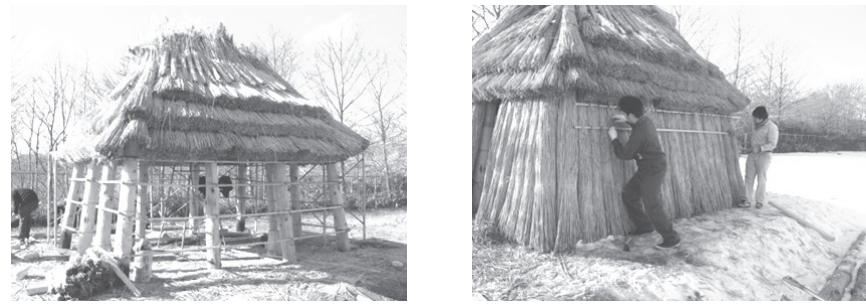

After 'Chisepuni' 注1), we constructed the wall.
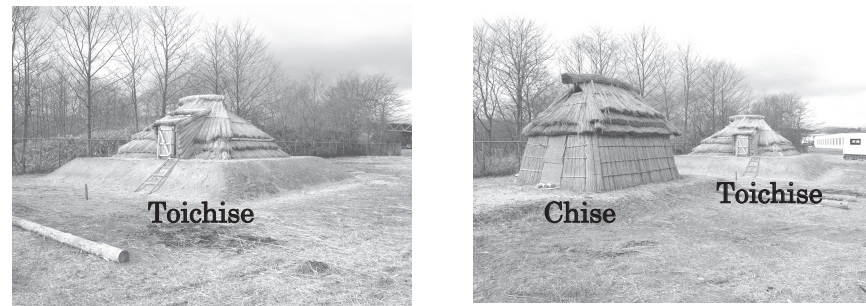

Fig. 1 Pictures of Chise

Table 1 Thickness of roof and wall

\begin{tabular}{|c|c|c|}
\hline & 茅莫の厚み & 備考 \\
\hline チセ & 屋根 : $30-45 \mathrm{~cm}$, 壁 : $10-15 \mathrm{~cm}$ & $\begin{array}{l}\text { Fig.1中段右のように茅束間は } \\
\text { 肎みがほとんどない場所もある }\end{array}$ \\
\hline 断熱改修チセ & 屋根 : $30-45 \mathrm{~cm}$, 壁 : $20-30 \mathrm{~cm}$ & $\begin{array}{l}\text { 室内勛からも壁を設置したため } \\
\text { 卓みは倍となった }\end{array}$ \\
\hline トイチセ & 屋根 : $30-45 \mathrm{~cm}$, 壁 : なし & 竪穴式住居であるため壁がない \\
\hline
\end{tabular}


Plan of Chise

Plan of Toichise

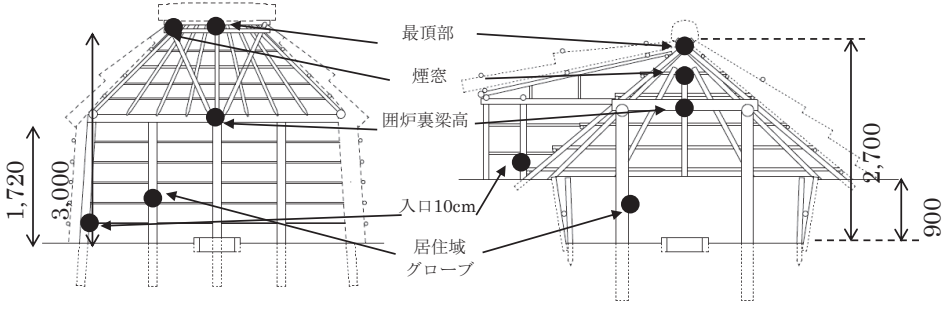

Section of Chise

Section of Toichise

Fig. 2 Plans and sections of each Chise 
軒高はおよそ $1720 \mathrm{~mm}$, 内部は間仕切りのない一間で直天井, 中央に内法で $320 \mathrm{~mm} \times 580 \mathrm{~mm}$ 程の囲炉裏を設けた（以上数值は実 測值）。木材の細かな加工は斧を用い，木材や茅の結束には麻紐や 縄を用いた. また, 一般的に知られているチセの構成は, 母屋にセ ムと呼ばれる前室がつくが, 文献20)にはセムの柱跡を持たない発 掘建物跡も紹介されている（pp.114-132），母屋の大小とセムの有 無の関係については確認できなかったが, 本研究においては, 工期 短縮の面からセムの附属しないチセを建設することとした。もちろ ん, セムの有無による室内環境の違いについて影響が全くないとは 言い切れないが, 後の実測結果からも示されるように, チセの温熱 環境の形成要因の最も大きなものは壁下部からの冷気の侵入であ り，それは，セムを作成したからといって防げるものではない。し たがって, 本チセの実測結果は, 一般的なチセの温熱環境を表して いるといって問題ないと考えている. なお, 今回使用した木材は地 場産材のカラマツ材を用いた。

\section{2 チセの断熱改修}

上記チセが完成した後, 炉を燃焼させたうえで厳冬期に一晚すご しつつ, 室温等の実測を2011年度に実施した。その際の環境は, 壁下部からの外気の流入が甚だしく，居住環境の視点で評価すると 大変㛜しいものであった。そこで，2012年度に再び実測を兼衩た 宿泊体験をする際，以下の断熱改修を行うこととした。

扉の仕様変更：これまで使い勝手を考慮し䈴を二枚重ねにしたも のを流用していたが, 直径 $10 \mathrm{~cm} \sim 15 \mathrm{~cm}$ 程の茅束を 3 つ縦に並心゙, 上下を茅押さえ材で固定したものに改めた。

壁の仕様変更 : 改修前は柱の外側に一重に茅束を葺いていたが, 室内側の柱間にも茅束を莫き, 壁の厚みを倍増させた（改修前の壁 厚 : $10 \mathrm{~cm} \sim 15 \mathrm{~cm}$ 程，改修後の壁厚 : $20 \mathrm{~cm} \sim 30 \mathrm{~cm}$ 程）。このよう に，壁を複層にして断熱性能を高める試みについては，アイヌへの 聞き取り調査の結果作られたマニュアル21)にも掲載されている.

\section{3 トイチセの建設}

2013年度はトイチセの建設を実施した。 チセの場合と同様に文 献調查，現地調查を実施したが，トイチセに関しては文献10)にある ように日本国内にあるトイチセは幕末上期にすでに失われている. また，冬の住居であるトイチセに関しては，山間部に作られている 場合が多く，発見されていない物がほとんどだろうと言われてい る。したがって，文献が非常に少なく，筆者らが発見できたのは文 献10) と文献11)のみである。このうち, 文献10)は樺太アイヌのト イチセに関して詳細に調查され, 平面図, 断面図等も掲載されてい る.この文献を参照すると, 所謂, 堅穴式住居様であることが分か る. そこで, 同様のプロジェクトを実施している大中遺跡を訪問 し, 工法, 実施体制等のヒアリングを行った後, 建設を行った ${ }^{12}$. トイチセの平面図, 断面図をFig.2の右側に示す.

\section{4. 温熱環境の測定}

\section{1 測定の概要}

前節1) 3)のそれぞれが終了した後, 宿泊体験を兼ねたチセ室内 の温熱環境の測定を2012年1月，12月，2013年12月の 3 回実施し た。測定項目は，チセ室内の温度（T\&D社製，TR-76Ui，TR $72 \mathrm{U})$ ）グローブ温度（T\&D社製，TR-51S），それぞれの測定時 間間隔は 10 分間である。また, 熱画像の測定（NEC AVIO社,
TVS-500EXZ）も実施した．Fig. 3はそれぞれの期間の外気温と風 速（10分間平均值）である。また，Table2は計測期間と天候であ る、いずれも近隣のアメダス観測点（白糠, 標高 $9 \mathrm{~m} ）$ のデータを 利用している，外気温は1)千セ測定時が最も低く，午前3時～6時は $-15^{\circ} \mathrm{C}$ を回っている。2)断熱于セの測定時は最低気温は約 $-10^{\circ} \mathrm{C}$, 3)卜イチセの測定時は $0^{\circ} \mathrm{C}$ である. 外部風の状況は1)，2）の測定時 は $2 \mathrm{~m} / \mathrm{s}$ と静穏であったが，3)の際にはそれらに比べると高い風速で あった，体感としては，その状況に合わせて薪を燃焼させるため， 単純な比較はできないが，下記1)の居住環境が最も過酷であった。

1)千セの測定

1回目の測定期間は，2012年1月19日の13時から 21 日の 8 時50分 までの 3 日間で，19日から 20 日の正午までは電気オイルヒーター (1000W)による予熱を行った状態で測定し，20日の午後1時から 21 日の8時50分までは宿泊体験を兼㸚て囲炉裏で火を焚いている状態 での測定を行った．参加人数は6名である. Fig.2に測定点を示す. グローブ温度の測定位置は囲炉裏からの輻射熱を受けや寸い位置 (囲炉裏のやや斜め方向) に設置し, 床から $90 \mathrm{~cm} の$ 高さに調整し た.

2)断熱改修チセの測定

上記チセの測定時においては, 非常に寒く, 全く就寝することが できなかった。そんため，第3節に記述したようにチセに対して断

Table 2 Periods and weather during measurement

\begin{tabular}{|l|l|c|}
\hline & \multicolumn{1}{|c|}{ 期間 } & 天候 \\
\hline チセ & $\begin{array}{l}\text { 2012/1/19 13:00—1/21 8:50 } \\
\text { 但し, 本報告で掲载しているのは } \\
1 / 206: 001 / 21 \text { 8:50 }\end{array}$ & 快晴 \\
\hline 断熱改修チセ & $2012 / 12 / 2115: 00-12 / 226: 00$ & 曇, 晴 \\
\hline トイチセ & $2013 / 12 / 2015: 00-12 / 216: 00$ & 曇, 雪 \\
\hline
\end{tabular}

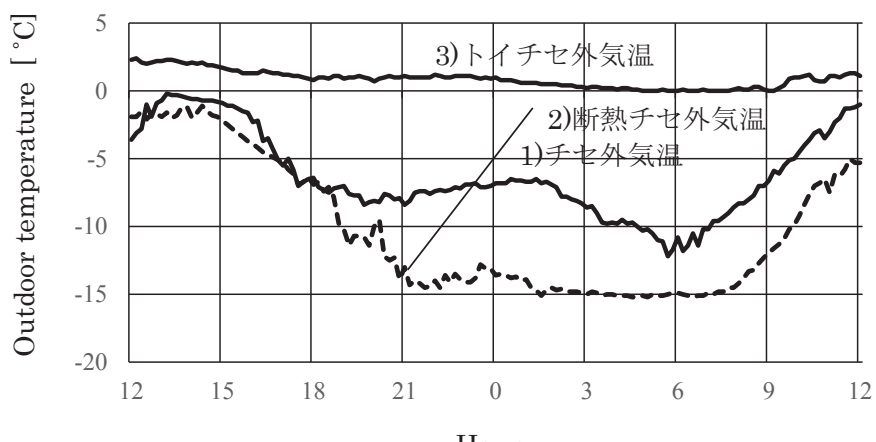

Hour

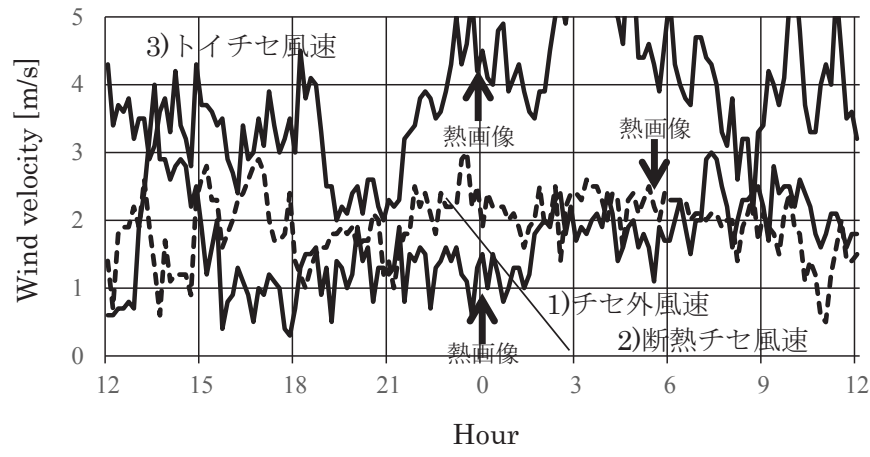

Fig. $3 \mathrm{Climate}$ in the measurements 
熱改修を施し，2回目の測定を実施した，測定期間は，2012年12月 21 日の 15 時から翌 22 日の 6 時までである. 参加人数は 6 名である. この際には電気オイルヒーターによる予熱は効果がないことから実 施しなかった。 また，冬期のチセでは床に茅束や莕束を敷いていた との記述があり21注5)，さらに，チセの測定時に底冷えがひどかっ たため，床に断熱材(EPS25mm)を敷いて過ごした． EPS25mmの 熱貫流率は $1.6 \mathrm{~W} / \mathrm{m}^{2} \mathrm{~K}$ であり，茅束の熱伝導率を $0.1 \mathrm{~W} / \mathrm{m}^{2} \mathrm{~K}$ （木材 と同程度）としたとき， $5 \mathrm{~cm} \sim 10 \mathrm{~cm}$ 程度の断熱性能と同等であり， 文献 21 や注 5 の記述とほぼ一致した条件での実測が行われたと考え ている.

\section{3)トイチセの測定}

トイチセの測定は 2013 年 12 月 20 日の 15 時から翌 21 日の 6 時まで である. 参加人数は 6 人で, 改修于セ時の測定に加え, 入口, 出口 の $\mathrm{CO}_{2}$ 濃度, 居住域のCO濃度の測定を実施した。

\section{2 各ヶースの内外温度差の推移}

Fig.4は各ケースの内外温度差の推移である。 それぞれのケース でチセの性能は異なるものの，燃焼空気の供給口である入口付近は 内外温度差が $0 \sim 10^{\circ} \mathrm{C}$ 程度，頂部付近は $20^{\circ} \mathrm{C}$ 以上の温度差がついて いるのがわかる。つまり，それほど大きくない一つの空間の中に

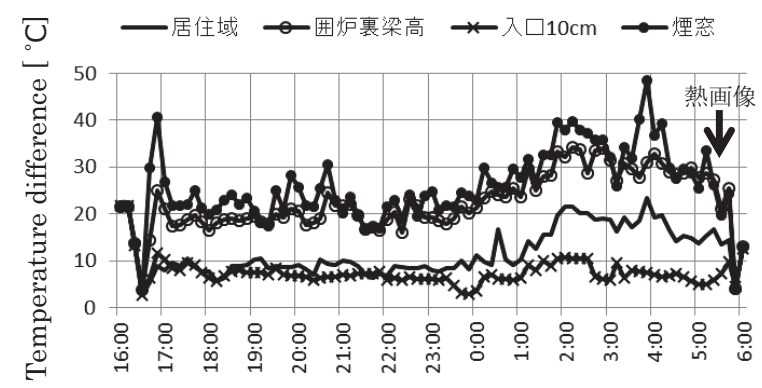

1) in Chise



2) in Chise with insulation retrofit

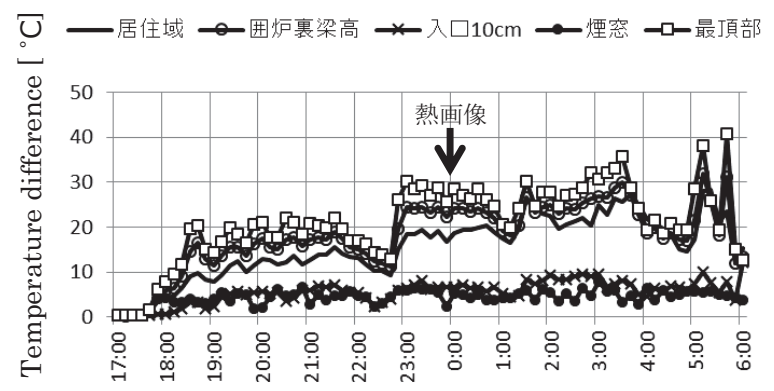

3) in Toichise

Fig. 4 Temperature difference between indoor and outdoor in each Chise $20^{\circ} \mathrm{C}$ 以上の温度差がついており, 建物の断熱性能が著しく低いこと がわかる。この原因となっているのが周囲から流れ込んでくる隙間 風である，千セの場合，壁と床の間には生じている隙間から，薪の 燃焼に伴って外気が侵入し，23時まで居住域の温度は全く上がら ず，非常に厳しい環境であった． 0 時～1時の間にそれまでの約三倍 の薪を投入することでようやく温度が上昇した．しかし，ござやブ ルーシートは使用していたものの，ほぼ，土間に直接座っていたた め, 底冷えがひどく, 朝方には座っていることができなくなった. 宇佐美らは前出の報告5) 7)で長期の加熱によって地盤面の温度が上 昇し, その効果によって室温が維持されると述べているが, 地盤表 面の温度は $5{ }^{\circ} \mathrm{C}$ 程度であり，そのような場所で長時間過ごすのは不 可能である. やはり，文献21や注5のように，なんらかの断熱を床 に施し, 囲炉裏周辺を除いて, 土間とは熱的な縁を切って生活して いたと考えるのが自然である.

次に，壁の断熱と雪による下部の気流止めを実施した断熱改修チ セでは居住域の温度は薪を焚き始めた直後から上昇し, 約 $20^{\circ} \mathrm{C}$ 保っていることがわかる。 また, 居住域と頂部の温度差もチセとは 違って発生しておらず, 現代の住宅とは生活する温度帯は違うが, 断熱, 気密性能の向上に対する行為が室内環境の質の向上（質とい うよりは単なる温度の上昇かもしれないが）に寄与している様子が 分かる. 後にFig.9で示寸ように, チセの熱損失の $2 / 3$ は換気による 損失であるため, 隙間風の防止に関する何らかの工夫はしていたと 考えられる21)ただ，その場合，換気量の不足から燃焼ガスが室内に 充満する可能性もある. 江戸期の松前藩の庶民住宅においては冬期 の換気量不足による目疾や脛の火傷による皮膚病が報告されている 1)。これは本州の住宅様式を持ちこんだ結果であるが, 長く寒冷地 に居住したアイヌが囲炉裏を使っていたことは事実であり, 他の効 果的な体温維持の方法を持っていたと想像できる.

トイチセの内外温度差は他の二つとは異なり, 薪の燃焼後から 徐々に温度差が広がっている様子がわかる．Fig.3のように，この 間，外気温は $0^{\circ} \mathrm{C}$ 近辺を保っており，竪穴式住居に特有の地盤の熱 容量の影響と考えられる. また, 前者とは異なり, 煙空の温度が全 く上昇しなかった，測定日は外部風速が高く，常時煙空からの吹き 込みがあったためと考えられる。そのような状況にあっても，上下 の温度分布は $10^{\circ} \mathrm{C} に$ 満たないものであった。 トイチセの場合も屋根

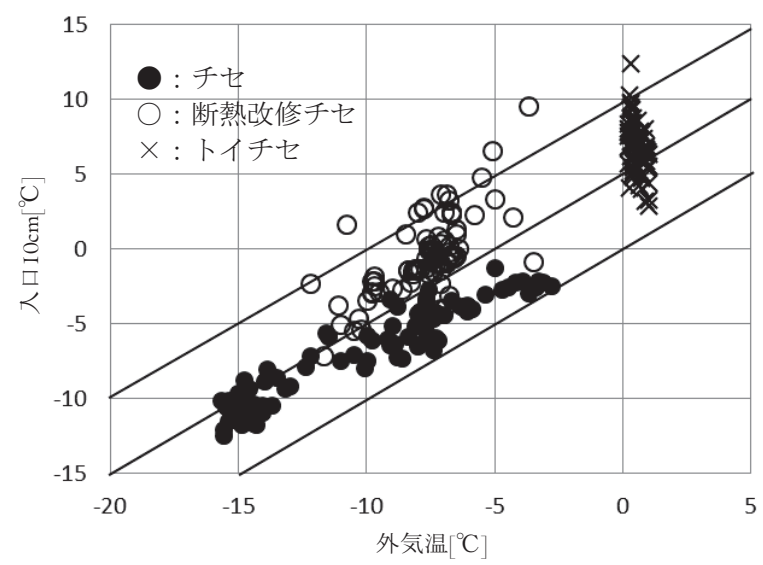

Fig. 5 Relationship between outdoor temperature and bottom temperature 
と地面の間に隙間がどうしても生じるが, チセと違い, 斜めに地面 に接触するため気密性能が上昇しや寸く, また，居住域から遠いた め, 流入した外気が居住域に到達するまでに, ある程度温度上昇す るためと考えられる.

Fig.5は10分毎に計測した同時刻の外気温と入口 $10 \mathrm{~cm}$ （流入外 気）の関係を表している，千セは外気温 $+5{ }^{\circ} \mathrm{C}$ の 中にほとんどおさ まっているが，断熱改修チセ，トイチセは $+5{ }^{\circ} \mathrm{C}$ 以上のデータがほ とんどである．どのチセも扉の気密性が全くないので外気の直接流 入は防ぐことはできないが，断熱改修チセ（雪による気流止め）,

トイチセ（流入口が居住域から遠い）のような工夫が床部の温度を 上昇させ，居住環境を和らげることになったと考えられる．

\section{3 各ケースの室内表面温度}

実測時には数時間おきにサーモカメラによって熱画像の撮影を 行い, 室内外表面温度の把握を実施した。Fig.6は各ケースの屋根 部，壁部のサーモカメラ画像である。それぞれの熱画像は外気温と 居住域の温度差が十分ある時間帯を選んだ結果，チセに関しては 5:30, 断熱改修于セ, トイチセは0:00の画像となった, それぞれ, 外気条件は異なり, チセ $-13^{\circ} \mathrm{C}$, 断熱改修于セ $-6^{\circ} \mathrm{C}$, トイチセ $1{ }^{\circ} \mathrm{C} て ゙$ ある. どの画像においても床付近の温度が低く, 頂部付近の温度が 高くなっており，上下の温度分布には約 $20^{\circ} \mathrm{C}$ の温度差が生じてい る。相互の比較に関しては，その状況に合わせて暖を得るために薪 を燃焼させており，単純な比較はできないが，他の二つに比べてチ セの温度分布が著しく低いことがわかる，もちろん，上述のように 外気温も $10^{\circ} \mathrm{C}$ 程度違うのだが，それ以上の差がそれぞれの熱画像 に生じている．最も大きな影響を与えているのは壁の下部の断熱, 気密性能と考えられる，千セの場合，この場所の性能が悪かったた めに, 薪の燃焼に合わせて大量の外気が侵入し, 床付近には- $10^{\circ} \mathrm{C}$ 以下のエリアが広く分布している。また，その空気を暖めるために 熱が消費されてしまうため屋根付近の温度も $10^{\circ} \mathrm{C}$ 以下である。そ れに対し，断熱改修チセは壁下部の気密性能が向上したため， $0^{\circ} \mathrm{C}$
以下の場所はほとんどなくなっている．また，トイチセは断熱改修 チセの実測を行った時と違い，雪がほとんどなく，気流止めの効果 は全くなかったにも関わらず，居住域に侵入してくる外気が触れる であろう場所の温度は $5^{\circ} \mathrm{C}$ 以上である. 温度の高い天井面からの再 放射によって周辺の温度が高くなり, その周辺を通過する外気の温 度を上昇させていると考えられる。

また，このように再放射を効果的に用いることができる点からも 床面には断熱を施した方が良いと考えられる.

\section{5. 標準発熱を用いたチセの熱環境性能の比較}

前節では，それぞれのチセで一晚を過ごした際の実測結果につい て紹介した. しかし, 本研究の目的の一つである, それぞれのチセ の熱環境性能の比較を行うためには, それぞれのチセで過ごした際 の薪の燃焼量が異なるため, 単純な比較が難しい. また, 薪を利用 した建物の性能を把握する場合, 薪の利用数をカウントし, それに 重量あたりの発熱量を乗じて発熱量を求め, その発熱量をもとに性 能值の算出を行うが (例えば文献14) ) 薪の含水率は様々であるた め，その值が信頼しうるものなのかは疑わしい，そこで，本報告で は燃料消費量と発熱量, $\mathrm{CO}_{2}$ 発生量の関係が安定した值として求め られており, また, 囲炉裏と同じような放熱形態である灯油のポー タブルストーブを用いて建物内を暖房し，断熱性能の推定を行っ た.

一般的な住宅の断熱性能の同定においては, 既知の発熱量に電気 ヒーターがよく用いられる15). しかし，千セを暖房している囲炉裏 においては $10 \mathrm{~kW}$ 超える熱を発生している場合もあり, 電気ヒー ターを用いて同じ発熱を得ることは不可能である。そこで，今回は 灯油ポータブルストーブを用いて暖房を行うこととした

（Fig.7）。また, 測定の前後に精密質量計をもちいてポータブル ストーブの重量を測ることで灯油の燃焼量を把握し, その量に灯油 の低位発熱量を乗じ，また，燃焼に要した時間で除すことで平均発
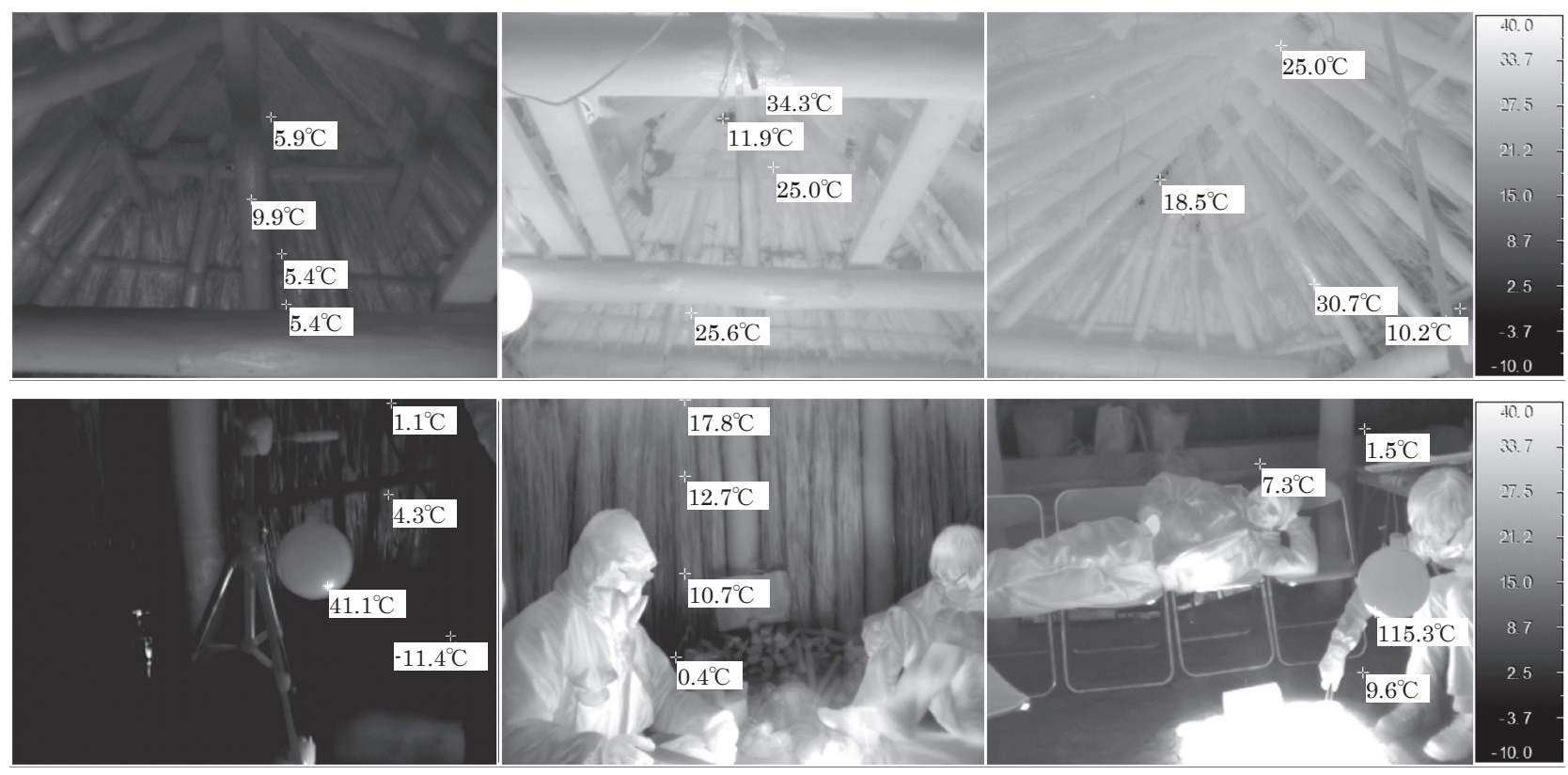

1) thermo view in Chise

2) thermo view in Chise with insulation retrofit

Fig. 6 Thermoview in each Chise 
熱量を算出した（(2)式）。また, 灯油が燃焼する際には二酸化炭 素が発生する. その量と室内外の二酸化炭素濃度から換気量を算出 した（(3)式，(4)式）。さらに熱収支式において換気熱損失と貫流 熱損失を分離することができる（(1)式）。これらの值を用いて断 熱改修チセとトイチセの熱環境性能を比較した.

Fig. 8はチセ, トイチセの内外温度差, $\mathrm{CO}_{2}$ 濃度差の推移の一例 である，測定は二時間行い，温度，二酸化炭素濃度は多少の変動は あるものの（特にトイチセ測定時の変動は外部風によるものと考え られる。）ともに約30分で定常に達しており，この際の平均值を 式(1)〜(4)に代入し総合熱貫流率を計算した，なお，実測は 4 月〜 5 月にかけての曇天，及び小雨の夕方から夜間にかけて実施したため 日射の影響は無視できたと考えている。

Fig.9はそれぞれのチセの換気損失, 貫流損失と暖房出力の関係 である. チセのように隙間の多い建物では暖房出力が増加するとそ の浮力によって換気（隙間風）による熱損失が増加すると考えられ る.それぞれの換気損失（のチセ，×トイチセ）を確認すると，右 上がりの傾向が認められ，また，チセの換気損失はトイチセの約 2 倍となっていることが分かる. 一方, 貫流損失はトイチセの方が少 し低いものの，概ね同じ值となっている，つまり，チセよりもトイ チセの方がトータルな断熱性能の点において優っており, 特に気密 性能の点, つまり，隙間風の防止の観点で優れているということが 確かめられた。この実測は断熱改修チセを用いているが積雪のない 時期に実施しているため壁の下端には隙間があり, 内外温度差の拡 大に伴って大量の隙間風が流入したと考えられる. チセもトイチセ も煙り出しの大きさほぼ同一であるし, また, 壁と地面の間を気密 化することができないのも同条件である，したがって，茅の地面へ の接触の仕方（チセはほぼ垂直であるが，トイチセの場合は斜めに 接触する）が隙間風の流入量の違いを生んでいると考えられる。 セの場合には，壁の下端部を土盛りして隙間風の流入を防止したと いう記述があるが，前述の雪を用いた改修の効果やこの結果から判 断すると，そのような手法は効果的だったと考えられる.

また，どちらのチセも総合熱貫流率は600～900W/K（熱損失係 数はチセ $87 \mathrm{~W} / \mathrm{m}^{2} \mathrm{~K}$, トイチセ $47 \mathrm{~W} / \mathrm{m}^{2} \mathrm{~K}$ である.）であり， $-20^{\circ} \mathrm{C}$ になる厳冬期に $10^{\circ} \mathrm{C}$ 程度注2)を維持しようとすると $20 \mathrm{~kW}$ 以の発熱 が必要になる。また，今回の実測の範囲でも換気損失に関しては発 熱量の増大に伴って換気損失が大きくなる傾向が認められここのよ

Table 3 Equations to measure thermal performance of Chise

$$
\begin{aligned}
& \bar{H}+(\overline{K S}+c \rho Q)\left(\theta_{o}-\theta_{i}\right)=0 \\
& \bar{H}=\left(w_{s}-w_{e}\right) k_{1} / \Delta T \\
& k_{2}=\left(w_{s}-w_{e}\right) k_{3} / \Delta T \\
& Q=k_{2} /\left(p_{i}-p_{o}\right)
\end{aligned}
$$


$c:$ 比熱 $[\mathrm{J} / \mathrm{kgK}], \rho:$ 空気の密度 $\left[\mathrm{kg} / \mathrm{m}^{3}\right]$ $\theta_{o}, \theta_{i}$ : 外気温, 室温 $\left[{ }^{\circ} \mathrm{C}\right], W_{s}, W_{e}$ : 初期, 終了時重量 $[\mathrm{kg}]$ $\Delta T:$ 測定時間 $[\mathrm{s}], k_{1}:$ 灯油低位発熱量 $[\mathrm{J} / \mathrm{kg}]$ $k_{1}:$ 灯油低位発熱量 $[\mathrm{J} / \mathrm{kg}], k_{2}: \mathrm{CO}_{2}$ 発生量 $[\mathrm{kg} / \mathrm{s}]$ $k_{3}:$ 灯油単位 $\mathrm{CO}_{2}$ 発生量 $\left[\mathrm{m}^{3} / \mathrm{kg}\right]$
うな場合，より換気損失の割合は増えると考えられる。このような 発熱をこの規模の空間で行うのは火災や空気環境への安全性から難 しい，また，夜間の温度維持をどのように行っていたか（もちろ
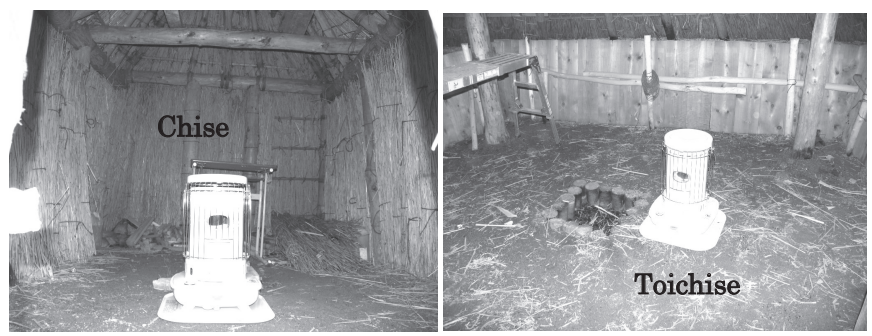

Fig. 7 Pictures of measurement

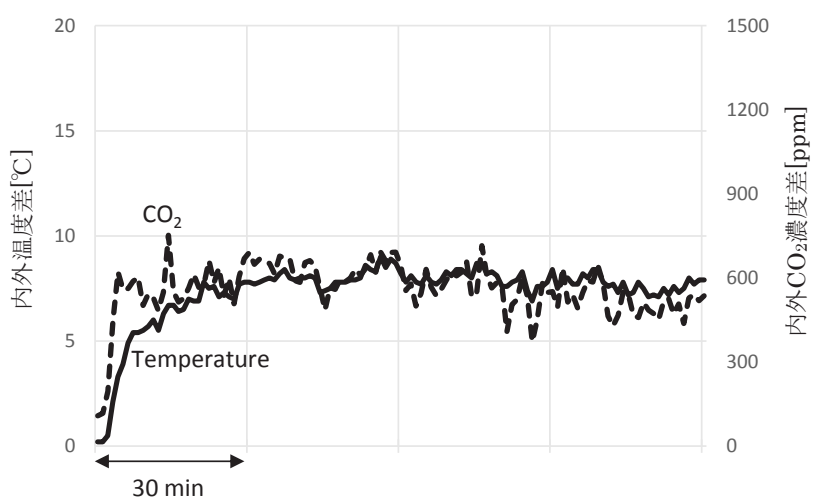

Change of temperature and $\mathrm{CO}_{2}$ in Chise with insulation retrofit (without snow)

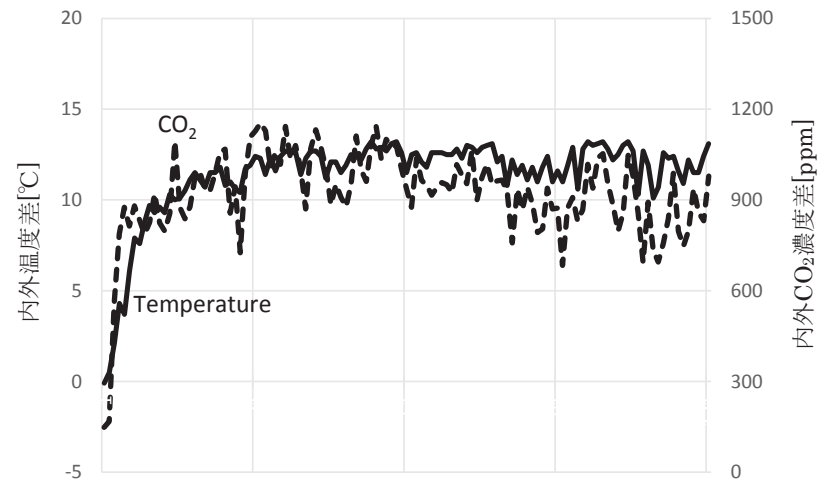

Change of temperature and $\mathrm{CO}_{2}$ in Toichise

Fig. 8 Change of temperature and $\mathrm{CO}_{2}$ in each Chise

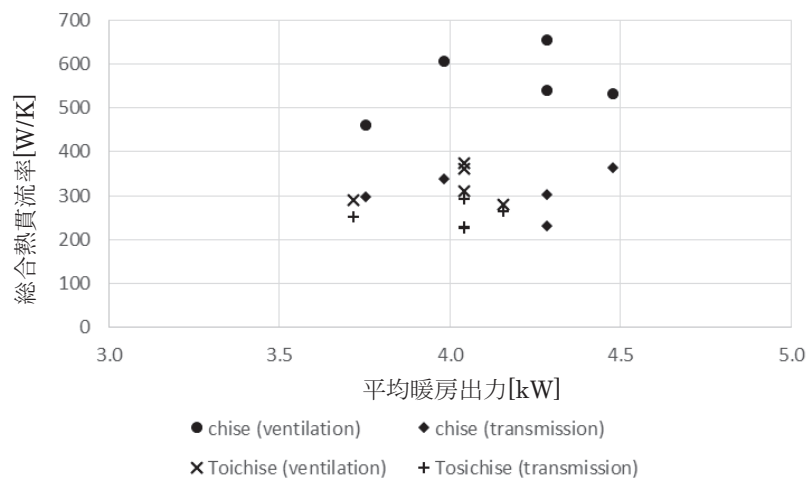

Fig. 9 Thermal performance of each Chise 
ん，寝具によるところは大きいが，外気温と同様の環境で生存する ことは難しいであろう。）を考えると, さらなる断熱性能の向上や 住居以外の工夫が必要である. 例えば, より厚い断熱被覆の利用, 衣服の工夫（毛皮の着用）, 食事の工夫（脂分の多い食事）であ る.

\section{6. まとめ}

北海道, 東北の先住民族であるアイ又の住生活を支えたチセとト イチセの冬期の室内環境がどのようであったかについての知見は少 ない. また, 現代になってからチセや復元チセの実測を行った結果 からは, 室内環境が非常に厳しかったという報告がある一方で, 非 常に暖かかったや地盤の熱容量の効果が著しかった等の報告もあ る.そこで, 温熱環境の実態を史料に基づいて再現したそれぞれの 復元チセを用いて測定し, その形成要因について分析した。 その結 果，以下のことがわかった。

1)断熱改修于セ, トイチセに比べ, 文献4でも述べられているよ うに, チセの厳冬期の温熱環境は劣悪で, 居住域はほとんど外気温 と同様の推移を示した。 その原因は建物下部からの隙間風の流入で あり, 断熱改修（壁厚の増加, 隙間風の流入防止）を行うことで居 住域の温熱環境は著しく改善した。

2)床断熱を行い地盤と熱的な縁を切ることで快適性が著しく向上 した. つまり, 文献5 7で述べられているような熱容量の効果に関 して顕著な効果は認められなかった.

3)以上から, 壁, 屋根ともに, 厚く茅を莫いていたこと, 床には 茅等が厚く敷き詰められていたこと, 壁下端部の地面との接触部分 には土盛りがされ，隙間風の侵入を防止していたことが示唆され た。

4)断熱改修チセ, トイチセに対して囲炉裏を模した標準発熱（灯 油ポータブルストーブ）を用いた熱環境性能の推定を実施した結 果, 断熱改修チセ（雪による気流止めなし）よりもトイチセの方 が，特に気密性能に関して優れていることがわかった．また，その 原因は壁を構成する茅束と地面の接触の仕方によるものと考えられ る.

\section{謝辞}

本研究は科学研究費補助金基盤 $\mathrm{C}$, トイチセの建設を通した体験 的環境教育に関する研究 (25350272) , 北方先住民族住居を用い た実践的教育プログラムの開発，北方先住民族住居を用いた実践的 教育プログラムの開発（00300509）（いずれも研究代表者は釧路 工業高等専門学校, 西澤岳夫）の補助を受けた記して感謝する。

また建設にあたって, 北海道開拓記念館, 小林孝二氏，明石工業 高等専門学校, 八木雅夫教授の指導を受けた.

また, データの分析にあたっては, 北海道大学アイヌ・先住民族 研究センター北原次郎太博士から多くの知見を頂いた。

最後に, 実測に参加していただいた釧路工業高等専門学校の学生 諸君に感謝する.

\section{注}

注1)チセプニについて

チセの建て方は通常の建築物（柱 $\rightarrow$ 屋根）という順番ではなく, 小屋組 $\rightarrow$ 柱一柱の上に小屋組みを乗せるという順番で行われたと言われている。こ
の柱の上に小屋組みを乗せる作業のことを「チセプニ」と言い, 重量のあ る小屋組みを持ちあげる」作業であるため多くの人数を要する.

注2)暖房室温について

例えば，文献14)では明治9年12月の開拓使の「箱製ノ火鉢ヨ撤シ煖炉ヨ用 フヘキ諭達」の口語訳を紹介しているが，その中で室内温度の目安は $16^{\circ} \mathrm{C}$ とされている.

注3)構造規模に関して

文献20)には発掘建物跡から住居の特徴を分析している章があり，そこで は凡そ10平方メートルのものから最大で 80 平方メートルに迫るものまで 様々な規模の住居跡が紹介されている，そこで今回建設したチセの規模は 補助金の額に見合ったものであること，建設機械を使わず手作業で冬を迎 える前に完成させることが可能であることを念頭に，同著を参考に決定し た

注4)壁の断熱に関して

文献21)の中で建設されたチセでは, 外だけでなく内側にも茅を莫く構法 を採用していた。

注5)敷物に関して

「樺太アイヌの穴居家屋「トイチセ」に就いて」では，床上に「…ヤソ草 (恐らくイワノガリヤスならん）を厚く敷き, その上にゴザをしいて居室 とする」とある。また，間宮倫宗口述の『北蝦夷図説』附図（1885），

「穴中」には，炉のまわりにコの字型に敷物が敷かれている様子が描かれ ている。これらの事から，敷物を用いて断熱することは一般的な手段で あったと推測される.

注6） $\overline{K S}$ (外皮総熱損失量) は総合熱貫流率を表す量記号であるが，ここで は, 総合熱貫流率より換気分を取り除き評価を行っている.

注7)トイチセにおける冬季の生活について

樺太アイヌのトイチセにおける冬季の生活については以下のような記録が 残っている.

1)菅元吉『唐太土人風俗図絵』「唐太土家」（1801）の絵図の説明文とし て、此処に起居するのは11月中から 2 月までとある

2)馬場脩『学界展望と東京と家』「樺太アイヌの穴居家屋「トイチセ」に就 いて」（1951）（参考文献10），トイチセの建設位置は夏の部落に近い樹 の多い風当たりの少ない所で, 冬籠りの時期は 11 月の中旬頃から 4 月下旬で ある（樺太アイヌの古老達を対象に行った聞き取り調査結果）

注8)茅束の熱伝導率

発熱箱（EPS5 cmで作成した $30 \mathrm{~cm}$ の立方体の内部に筒状の面状発熱体を設 置) の上部に茅束を設置して $30 \mathrm{~cm}$ 茅束と EPS $5 \mathrm{~cm}$ の発熱量と内外温度差の 関係式を作成した。

$U_{i} A_{b}+U_{i} A_{s}=0.64 \quad$ (5)

$U_{i} A_{b}+U_{k} A_{s}=0.68 \quad$ (6)

ここで, $U_{i} A_{s}$ を $0.0611(\mathrm{EPS} 5 \mathrm{~cm}, 30 \mathrm{~cm} \times 30 \mathrm{~cm})$ とすると， $U_{k}$ は 0.579 とな

り, $\lambda_{k}$ は $0.44 \mathrm{~W} / \mathrm{mK}$ と推定できる. 木質材料の熱伝導率は $0.1 \sim 0.3 \mathrm{~W} / \mathrm{mK}$ であ るが, この測定は茅莫屋根用の性能測定であり，空気の流通がある．床に 敷いた場合は空気の流通は非常に少ないと考えられるので茅束の熱伝導率 は木質材料と同等と考えることができるとした.

記号 $U_{i}$ : 断熱材の平均熱貫流率, $A_{b}$ : 断熱材の面積, $A_{s}$ : 蓋部の面積, $U_{k}$ : 茅の熱貫流率， $\lambda_{k}$ : 茅の熱伝導率

注9)灯油の潜熱の影響について

灯油は燃焼時に水蒸気を発生するため, それが凝縮した場合に熱損失係数 の計算に影響を与える可能性がある。灯油の低位, 高位発熱量はそれぞれ 43. 5, 46. 5MJ/kgである. この差の $3 \mathrm{MJ} / \mathrm{kg}$ が潜熱分であるが, 全て凝縮熱が

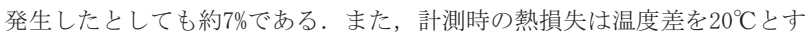

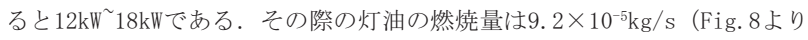

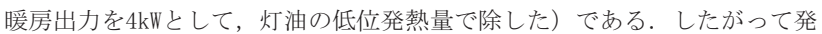
生する潜熱は最大でも $276 W$ (約 $2 \%$ ) となり熱貫流率の精度（有効数字 2 桁） に及ぼす影響は小さいと言える.

\section{参考文献}

1) 遠藤明久: 北海道住宅史話（上）, 住まいの図書館出版局, 星雲社

2) http://ja. wikipedia. org/wiki/\%E3\%83\%81\%E3\%82\%BB ,2014/7/9

3) 小林孝二:アイヌの建築文化再考一近世絵画と発掘跡からみたチセの現像 一, 北海道出版企画センター, 2010

4) 窪田英樹, 萱野茂, 岸下浩治, 小笠原康志:アイヌ民族伝統住居チセの冬期室 内環境, 空気調和・衛生工学会論文集 (41), pp. 1-10, 1989.10

5) 宇佐美智和子, 玉川和浩, 峰尾孝, 木村知子: 伝導型地中熱活用住宅の研究, その1アイヌ住居「チセ」に倣った地熱住宅の温熱環境, 日本建築学会大会 
学術講演梗概集D-2, 環境工学II, pp. 643-644, 2003

6) 宇佐美智和子, 青柳信克, 花岡利昌, 磯田憲生:アイヌ住居(チセ)の長期温度 測定, 土間床の地中温度について, 日本建築学会北海道支部研究報告集

(63), pp. 165-168, 1990. 03

7) 宇佐美智和子, 青柳信克, 花岡利昌, 磯田憲生:アイヌ住居 (チセ)の長期温度 測定, イロリ加熱による土間床への蓄熱, 日本建築学会北海道支部研究報告 集. 計画系 $(62) ， 65-68 ， 1989.03$

8) 西澤岳夫, 森太郎ほか: 北方先住民族住居を用いた実践的教育プログラムの 開発 その3 2011年度活動報告〜，日本建築学会北海道支部研究報告集 (85), pp. 495-498, 2012.6

9) 西澤岳夫, 森太郎ほか: 北方先住民族住居を用いた実践的教育プログラムの 開発 その4 ～2012年度活動報告 , 日本建築学会北海道支部研究報告集 (86), pp. 425-428, 2013.6

10) 馬場脩: 樺太アイヌの穴居家屋「トイチセ」について, 八学会年報第三 集, pp. 121-133, 1951. 12

11) 加藤九祚: 間宮林蔵の見たギリヤク族 (1), 国立民族学博物館研究報告 1 (2) , pp. 305-333, 1976. 7

12) 八木，角野: 国指定史跡播磨大中遺跡における地域素材を活用した竪穴住 居復元プロジェクト, 平成23年度全国高専教育フォーラム, https:// www. kosenforum. kosen-k. go. jp/2011/entry/genko/00228. pdf, 2014/7/8

13) 荒谷登: 暖房以前の問題, 建築雑誌 84(1006), pp. 115-117, 1969.02

14) リジャル ホム バハドゥル他:ネパール山岳地帯の伝統的住宅における冬 季の温熱環境調査, 日本建築学会計画系論文集 , 546号, pp. 37-44, 2001. 08

15）服部他: 戸建住宅の熱損失係数に関寸る実用的現場実測法の開発と実測 例 ，日本建築学会技術報告集，14巻，28号，pp. 491-496，2008. 10

16) R・ヒッチコク: 北構保男訳, 世界の民族誌 1 アイヌ人とその文化 一明治 中期のアイヌの村から一,株式会社 六興出版, 1985.4

17) 絵内正道, 荒谷登: 居住室の温熱環境の実態, その1 寒さに応じた住い方と 室温変動パターンについて, 日本建築学会論文報告集, 264号, pp. 91-98, 1978. 02

18) 絵内正道, 荒谷登: 居住室の温熱環境の実態, その 2 寒さに応じた住い方 と設定室温について, 日本建築学会論文報告集，265号,pp. 105-113, 1978. 03

19）北構保男：世界の民族誌 I，アイヌ人とその文化一明治中期のアイヌの 村から一, 六興出版, 1985

20) 小林孝二：アイヌの建築文化再考 一近世絵画と発掘跡からみたチセの原 像-，北海道出版企画センター，2010

21) 財団法人 アイヌ文化振興・研究推進機構：アイヌ生活文化 再現マ ニュアル 建てる, http://www. frpac. or.jp/manual/files/2000_01.pdf ,2014/12/1

22) 都築和代 : 冬期の低温環境が睡眠時の体温および睡眠に及ぼす影響, 日 本建築学会大会学術講演梗概集, D-2, 環境工学 II, pp415-416, 2007 


\title{
THERMAL ENVIRONMENT OF CHISE AND TOICHISE IN WINTER SEASON
}

\author{
Taro MORI* , Takeo Nishizawa **, Kouhei KUWABARA** \\ and Syoji SATOU*** \\ * Assoc. Prof., Faculty of Eng., Hokkaido Univ., Dr.Eng. \\ ** Assoc. Prof., Dept. of Arch., Kushiro National College of Technology, Dr.Eng. \\ *** Prof., Dept. of Arch., Kushiro National College of Technology, Dr.Eng.
}

\begin{abstract}
Introduction
Recently, there are many environmental issue around the world. Most of them are caused by modernization of our life. Then people pay attention to a life style of indigenous people. Because they didn't use any fossil fuel until recently. Also, their culture level is very high. Their life style can be a text book for people who live with huge energy consumption. Chise is the traditional house for Ainu people who live in Hokkaido and northern Asia as indigenous people. They were made of just local materials such as wood and cogon grasses. There are some research on Chise, but most of all are about housing type. Few researches were conducted for thermal environment and method to survive through severe cold weather. Moreover, those research indicate different results. One indicates Chise is well suited for winter season by heat from ground, because Ainu people had always used hearth through the year. It heat a ground under a floor. The other is not suited for winter season. There is an infiltration caused by hearth. It makes indoor environment severe.

In this report, we made two different types of Chise and measure the thermal environments in severe cold weather. The results indicate thermal environment in each Chise is very poor. But Toichise is better than Chise. They probably had some method except housing to get warm in cold environment.
\end{abstract}

\section{Construction of Chise}

In this research, two different types of Chise were constructed. The One is Chise, stilt house. Chise is the general type of traditional house for Ainu people in Hokkaido. The other is Toichise, pit-house. Toichise was lost until the latter part of Edo period in Hokkaido. Although, some literature and pictures of Toichise in Kasrafuto area can be found. We constructed Chise in 2011 and make retrofit for cold climate in 2012 by Grant-in-Aid for Scientific Research (KAKENHI). Also, we constructed Toichise in 2013 by another Grant-in-Aid for Scientific Research (KAKENHI). The construction method for Chise followed historical material published by the Ainu museum. That for Toichise followed the material published by Akashi National College of Technology. We tried not to use modern materials and construction equipment, when we constructed Chises.

\section{Measurement of thermal environment}

We measured the thermal environment in Chise on Jan., 2012 and Chise with retrofit on Dec., 2012, respectively. We also measured the thermal environment in Toichise on Dec. 2013. The measurement of air temperature, humidity, surface temperature by thermo-viewer were conducted in each measurement. Also, we compared the thermal performance of each Chise by the results of the measurement of heating powers by using kerosene heater and air temperatures.

\section{Result and Discussion}

The thermal environments in each Chise on severe cold weather are poor. Especially, that in Chise was very poor. The temperature at floor level was as same as outdoor temperature, because infiltration from the bottom area was huge. Then, the retrofit for Chise improve the thermal environment.

The comparison of the thermal environments indicates that the thermal performance of Toichise is better than Chise with retrofit. Especially, the air tightness of Toichise is better than retrofit Chise. those results indicate that 1. they, Ainu people used floor insulation by using cogon grasses, 2. they improved the air tightness by cover the bottom of the wall, 3. they were able to survive not only by the thermal performance of their dwelling but also by good clothes through severe winter. 